Article

\title{
Electrochemical Fingerprint of CuS-Hexagonal Chemistry from \\ (Bis(N-1,4-Phenyl-N-(4-Morpholinedithiocarbamato) Copper(II) Complexes) as Photon Absorber in Quantum-Dot/Dye-Sensitised Solar Cells
}

\author{
Mojeed Adedoyin Agoro ${ }^{1,2, *(\mathbb{D}}$, Edson Leroy Meyer ${ }^{2, *} \mathbb{\infty}$, Johannes Zanoxolo Mbese ${ }^{1, *(\mathbb{D}}$ and \\ Kwabena Manu ${ }^{3}$ \\ 1 Department of Chemistry, University of Fort Hare, Private Bag X1314, Alice 5700, South Africa \\ 2 Fort Hare Institute of Technology, University of Fort Hare, Private Bag X1314, Alice 5700, South Africa \\ 3 Department of Computer Science, University of Fort Hare, Private Bag X1314, Alice 5700, South Africa; \\ kwabeemanu@gmail.com \\ * Correspondence: magoro@ufh.ac.za (M.A.A.); emeyer@ufh.ac.za (E.L.M.); jmbese@ufh.ac.za (J.Z.M.); \\ Tel.: +27-781246437 (M.A.A.); +27-792403201 (E.L.M.); +27-728385150 (J.Z.M.)
}

Received: 10 February 2020; Accepted: 27 February 2020; Published: 6 March 2020

check for updates

\begin{abstract}
The main deficit of quantum dot/dye-sensitised solar cells (QDSSCs) remains the absence of a photosensitiser that can absorb the entire visible spectrum and increase electrocatalytic activity by enhancing the conversion efficiency of QDSSCs. This placed great emphasis on the synthesis route adopted for the preparation of the sensitiser. Herein, we report the fabrication of hexagonal copper monosulfide (CuS) nanocrystals, both hexadecylamine (HDA) capped and uncapped, through thermal decomposition by thermogravimetric analysis (TGA) and a single-source precursor route. Morphological, structural, and electrochemical instruments were used to assert the properties of both materials. The CuS/HDA photosensitiser demonstrated an appropriate lifetime and electron transfer, while the electron back reaction of CuS lowered the electron lifetime in the QDSSCs. The higher electrocatalytic activity and interfacial resistance observed from current density-voltage (I-V) results agreed with electrochemical impedance spectroscopy (EIS) results for CuS/HDA. The successful fabrication of hexagonal CuS nanostructures of interesting conversion output suggested that both HDA capped and uncapped nanocrystals could be adopted in photovoltaic cells.
\end{abstract}

Keywords: single-source precursor; quantum dots; photosensitiser; electrocatalystic; photovoltaic cells

\section{Introduction}

A main current challenge is the high rate of energy consumption and environmental degradation from the use of fossil fuels. Therefore, it is necessary to search for a new alternative that is not only environmentally friendly, but also a sustainable solution to the energy crisis [1]. Therefore, the need for clean, sustainable, and renewable energy has become a top priority. Various innovations, such as biomass, heat, solar energy, and fuel gas have been adopted for the conversion of energy to electricity [2-5]. In recent times, solar energy has emerged as a popular source of energy. This is because solar energy is clean, sustainable, and abundantly available across many regions of the world. Due to its abundant supply, solar cells, known as photovoltaic cells, are used to directly convert sunlight to electricity through the aid of photochemical and photoelectric effects, i.e., silicon-based cells and quantum-dot/dye-sensitised solar cells (QDSSCs). However, the use of photovoltaic cells remains a 
challenge, as they are unable to produce large-scale energy for commercialisation [6,7]. The theoretical efficiency of $44 \%$ of QDSSCs as a result of multiple excitons has given them a strong edge over the Shockley-Queisser limit. This multiple-exciton generation accounts for the adoption of quantum dots (QDs), owing to their excellent attributes that include easy fabrication, size dependence, and a turnable band gap.

Due to this quality, QDSSCs are considered promising photovoltaic cells, evidenced by the high levels of research interest in this field [8-15]. This has emphasised the choice of semiconductors that could harvest the entire solar spectrum through their use as QD sensitisers. A major class of semiconductors consists of metal sulfide semiconductor-based photocatalysts that can alter size distribution without changing chemical constituents [16,17]. Copper monosulfide (CuS) has distinguished itself among metal sulfides owing to its different band gap and various morphologies. This makes CuS a hot-spot semiconductor material with great potential in the field of photocatalytic and photovoltaic applications [18-26]. Hexagonal covellite- CuS with a bandgap of $\sim 2 \mathrm{eV}$ and a p-type-enhances absorber abilities to cover the entire solar spectrum [18,19]. Furthermore, $\mathrm{CuS}$ absorbs the infrared area through plasmonic absorption emanating from copper valencies due to a high concentration of charge carriers $[20,26,27]$. Integration of $\mathrm{CuS}$ with $\mathrm{TiO}_{2}$ can enhance photon-absorption properties to visible regions, leading to better conversion efficiency. The major challenge when integrating these elements is the synthesis of QD photosensitisers and deposition on a $\mathrm{TiO}_{2}$-coated electrode. Deposition of the photosensitiser on the semiconductor electrode occurs via either ex situ or in situ routes [28,29].

In situ routes are solely electrochemical deposition, successive ionic-layer-adsorption reaction, and chemical-bath deposition, but cannot give accurate size distribution. Ex situ routes are direct adsorptions, molecular linker attachment, and electrophoretic deposition, and they separately fabricate the photosensitisers before injecting it with the coated electrode [15]. This study adopted the single-source-precursor route for the synthesis of QD sensitisers through the injection of HDA and oleic acid (OA) to influence their size, morphologies, and structural properties. Direct deposition was used to add the QD sensitisers on the coated electrode by immersing both in a solution for a period of time.

\section{Results and Discussion}

\subsection{X-Ray Diffraction of Metal Sulfide Nanoparticles}

The preferred crystal and crystallinity orientation of CuS/HDA and CuS sensitisers was studied through the XRD instrument. Figure 1 shows the diffraction configuration of the sensitisers. The XRD results of CuS/HDA agreed with atomic-force-microscopy (AFM) results, indicating good surface roughness. Crystalline purity and quality were displaced by the strong and sharp diffraction peaks observed in the samples. The observed XRD peaks were indexed by using space group 194: P63/mmc, producing the pure hexagonal covellite crystal structure phase of CuS. Additional XRD peaks emanated from the unreacted ions, but impurities were not observed. There were basically high-intensity diffraction peaks for $\mathrm{CuS} / \mathrm{HDA}$ at $22.2^{\circ}, 26.1^{\circ}, 26.4^{\circ}, 27.4^{\circ}, 33.2^{\circ}, 34.6^{\circ}, 38.6^{\circ}, 49.2^{\circ}, 52.3^{\circ}, 55.9^{\circ}, 62.4^{\circ}$, $66.2^{\circ}, 78.9^{\circ}$, and $81.1^{\circ}$. These peaks were related to lattice planes of (101), (102), (103), (008), (110), (108), and (116) (PDF 06-0464) as the hexagonal covellite CuS phase [30]. However, as shown in Figure 2, $\mathrm{CuS}$ revealed a nonstoichiometric mixed phase of the covellite as the main phase and could be indexed using JCPDS 06-0464. This indicated space group 194: P63/mmc and 62: Pnma, respectively, for CuS. Peak values observed at $2 \theta$ equalled $16.3^{\circ}, 21.9^{\circ}, 22.7^{\circ}, 23.4^{\circ}, 25.9^{\circ}, 26^{\circ}, 30.2^{\circ}, 32.1^{\circ}, 35.8^{\circ}, 39.8^{\circ}, 41.7^{\circ}$, $43.1^{\circ}, 46.4^{\circ}$, and $51^{\circ}$. These were related to the (101), (102), (103), (008), (110), (108), and (116) hexagonal $\mathrm{CuS}$ crystal [31]. The presence of these lower intensities and minor phases are usually linked to defect chemistry, and the thermodynamics of the solid and thermal gradient. This was caused by internal origins, as described elsewhere [32]. 

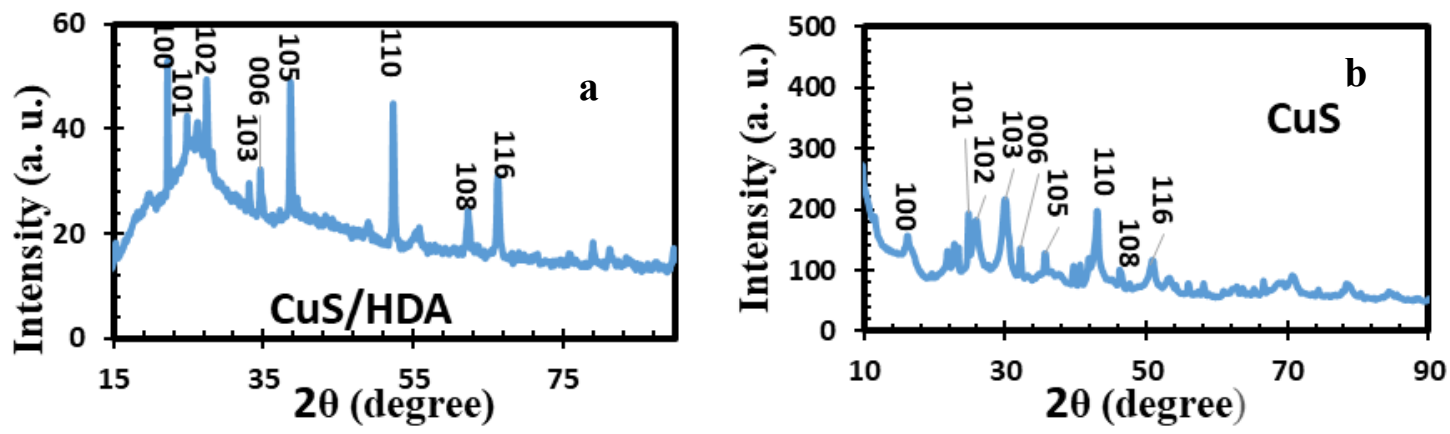

Figure 1. XRD spectra of (a) copper monosulfide (CuS)/HDA and (b) CuS nanoparticles.
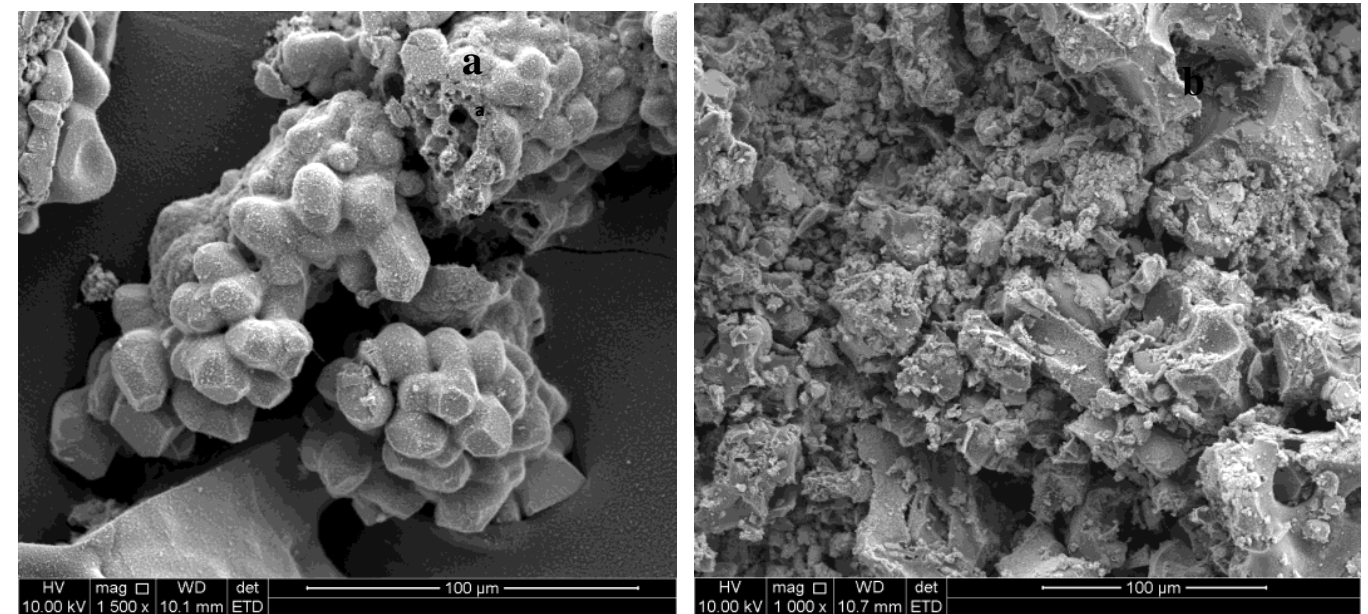

Figure 2. SEM images of (a) CuS/HDA and (b) CuS nanoparticles.

\subsection{SEM of Metal Sulfide Nanoparticles}

SEM morphology for CuS/HDA and CuS is shown in Figure 2. The displayed SEM micrographs corresponded to hexagonal and spherical nanoparticles with agglomeration for both samples, exhibiting a reasonably smooth surface with little microspheres. The shapes displayed in the image implied that $\mathrm{CuS}$ had a good crystal structure that provided a more catalytic reduction of the HI-30 electrolyte, and supports previous reports by [33,34].

\subsection{Atomic-Force Microscopy of Metal Sulfide Nanoparticles}

The surface roughness of two photosensitiser films was evaluated by AFM, providing 3D and 2D images of CuS/HDA and CuS sensitisers (see Figure 3). The CuS/HDA and CuS films exhibited surface roughness in the ranges of 23.9-239 $\mathrm{nm}$ and 0.16-1.69 um, respectively. AFM analysis revealed a smaller percentage for the CuS/HDA film than for the CuS films. The CuS film displayed good size roughness. These promoted electrocatalytic activity with the iodide redox electrolyte [35]. These results connoted that CuS/HDA film charge transfer resistance (Rct) at the $\mathrm{TiO}_{2} /$ iodide electrolyte interface could be very low. $\mathrm{TiO}_{2}$ and $\mathrm{CuS}$ displaced higher roughness through better contact bonding. Results revealed more electrocatalytic activity for the $\mathrm{CuS}$ film on a $\mathrm{TiO}_{2}$ surface, with good reaction with an HI-30 redox couple iodide electrolyte [36]. The conversion efficiency of the QDSSCs relied majorly on better material surface roughness. The improvement of surface roughness tended to improve the electrocatalytic performance of the system. Therefore, $\mathrm{CuS}$ on $\mathrm{TiO}_{2}$ reduced surface resistivity, which connoted improved short circuit current (Jsc) and power-conversion efficiency [37]. 

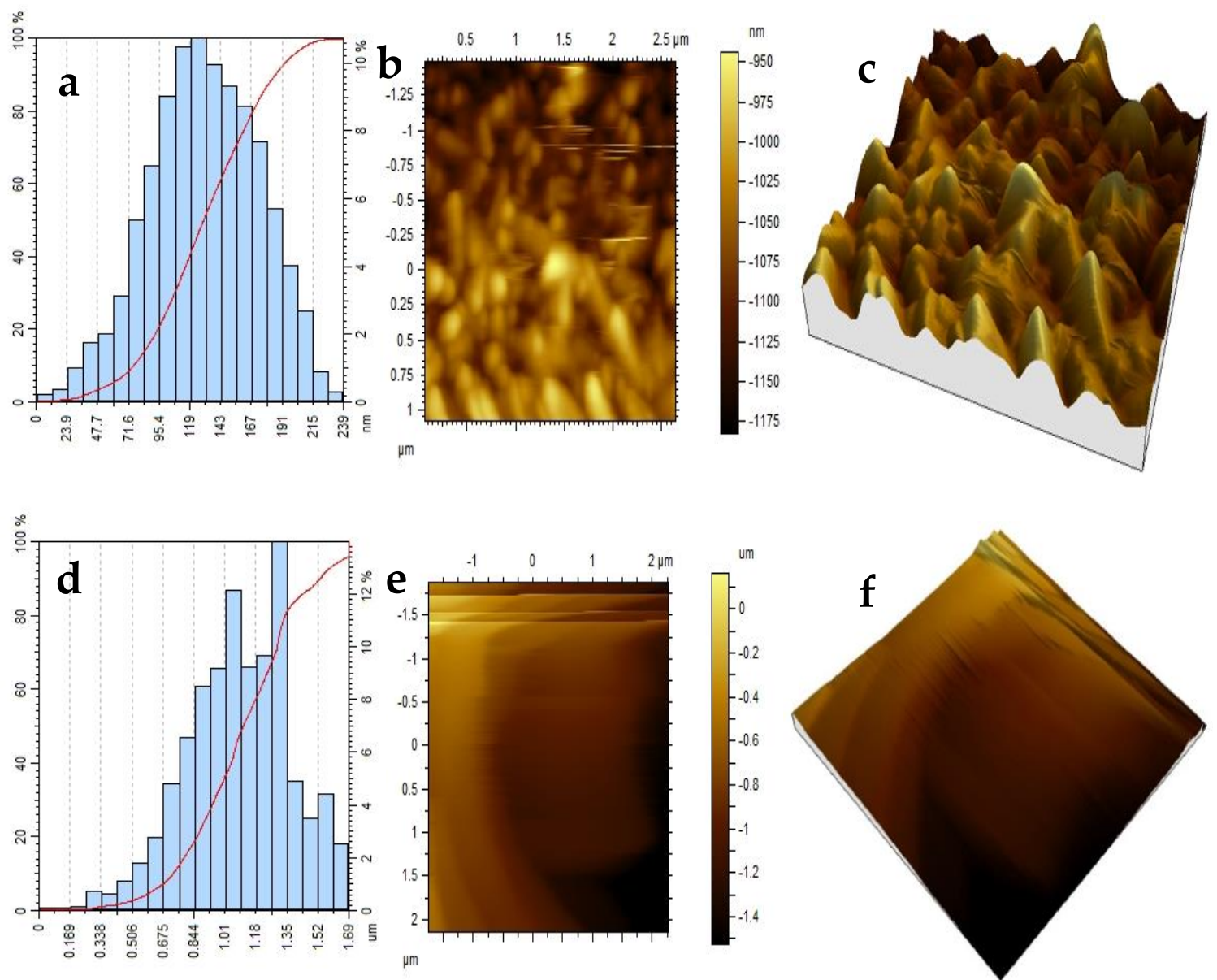

Figure 3. Atomic-force-microscopy (AFM) images of: (a) CuS height profile; (b) CuS nanoparticles in 2D; (c) CuS nanoparticles in 3D; (d) CuS/HDA height profile; (e) CuS/HDA nanoparticles in 2D; and (f) CuS/HDA nanoparticles in 3D.

\subsection{Cyclic-Voltammetry Results}

The cyclic-voltammetry (CV) spectra for CuS/HDA and CuS photosensitisers, as seen in Figure 4, strongly displaced the irreversibility and reversibility attributes of both sensitisers. The shifting of redox peaks strongly exhibited the performance of the $\mathrm{CuS} / \mathrm{HDA}$ sensitiser. At $50 \mathrm{mV} / \mathrm{s}$, the reduction and oxidation peaks of CuS/HDA sensitisers were shifted in the corresponding directions. This was due to the expansion of the redox peaks by the inability of the materials to complete activation when a current was applied [38,39]. The highest-occupied-molecular-orbital (HOMO) levels and lowest-occupied-molecular-orbital (LUMO) levels were considered the most important developments for photosensitiser regeneration and electron injection. It has been reported that the enhancement of electron transfer is linked to LUMO conductivity bands and closeness. This connotes that there was sufficient mobility force from the LUMO levels to the conduction band of CuS/HDA [40-43]. The almost rectangular $\mathrm{CV}$ profile of $\mathrm{CuS}$ indicated ideal energy-storage behaviour. However, the presence of redox peaks (oxidation and reduction) observed within the scanned potential range of CuS, implied that the CuS nanostructure has a multilayer composite of higher reversibility and stability $[44,45]$. The nanostructured CuS photosensitiser could be further optimised to enhance electrical conductivity. 

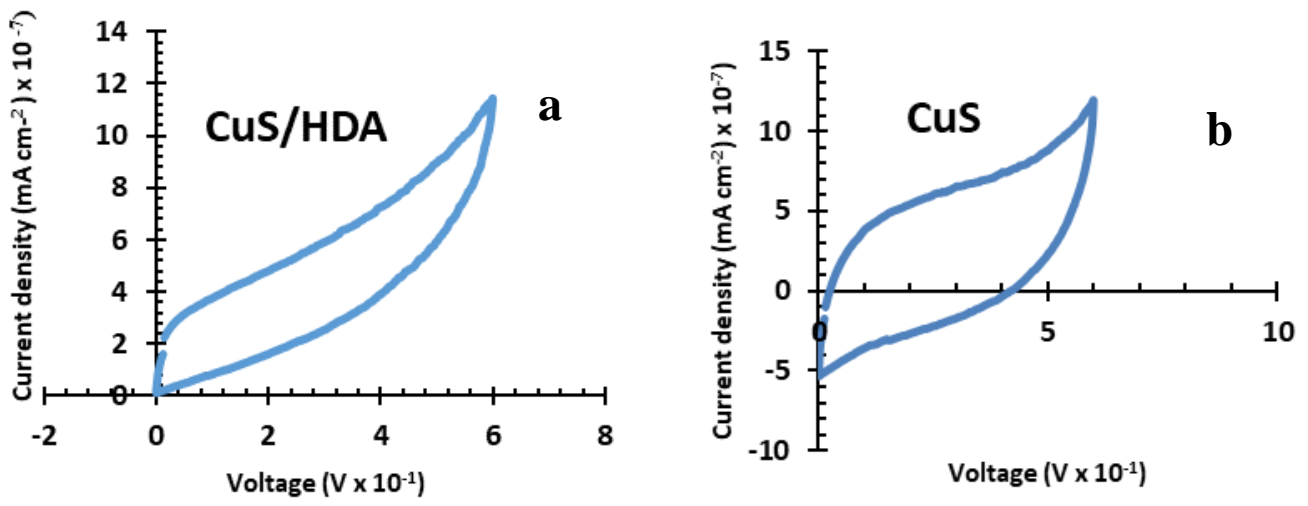

Figure 4. Cyclic-voltammetry (CV) spectra of (a) CuS/HDA and (b) CuS nanoparticles.

\subsection{Electrochemical-Impedance Spectroscopy (EIS)}

EIS plots (displayed in Figure 5) showed a typical semicircle at the high-frequency region and a straight line at the low-frequency region. EIS results of both CuS/HDA and CuS sensitisers showed similar trends to the obtained results from CV (see Figure 4). Series resistance (Rs) is displayed by the nonzero intercept of the real axis, indicating high frequency while the middle-frequency semicircle was attributed to the Rct at the CE/electrolyte interface. We employed EIS to compare the Rct between the HI-30 electrolyte and the photosensitisers. Both photosensitisers possessed good catalytic activity. The Rct for CuS/HDA was much smaller compared to the Rct of CuS, which connotes that CuS/HDA photosensitiser had excellent charge transfer at the interface of the electrolyte and the photanode. The recombination of electrons in $\mathrm{TiO} 2$ with acceptors in the electrolyte is normally referred to as the electron lifetime. In this study, the electron recombination of CuS/HDA was effectively suppressed [46-50]. This indicated that the CuS/HDA sensitiser displayed a higher level of electrocatalytic activity compared to CuS [51], due to its high specific surface area and strong adhesion to fluorine-doped tin oxide (FTO). This result is in good agreement with the Bode plot (see Figure 6) and I-V (see Figure 7). The semicircle is also a well-established indication of Rct [52-54].

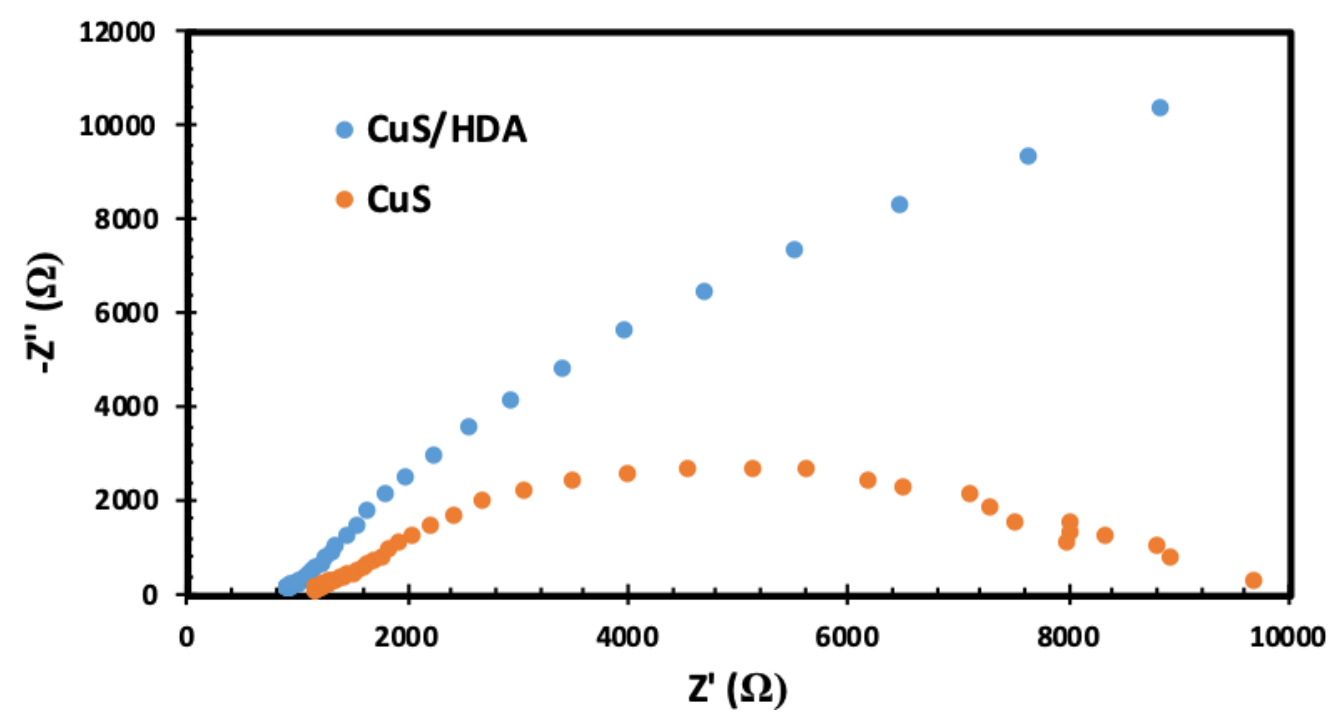

Figure 5. Electrochemical-impedance-spectroscopy (EIS) spectra of CuS and CuS/HDA nanoparticles. 

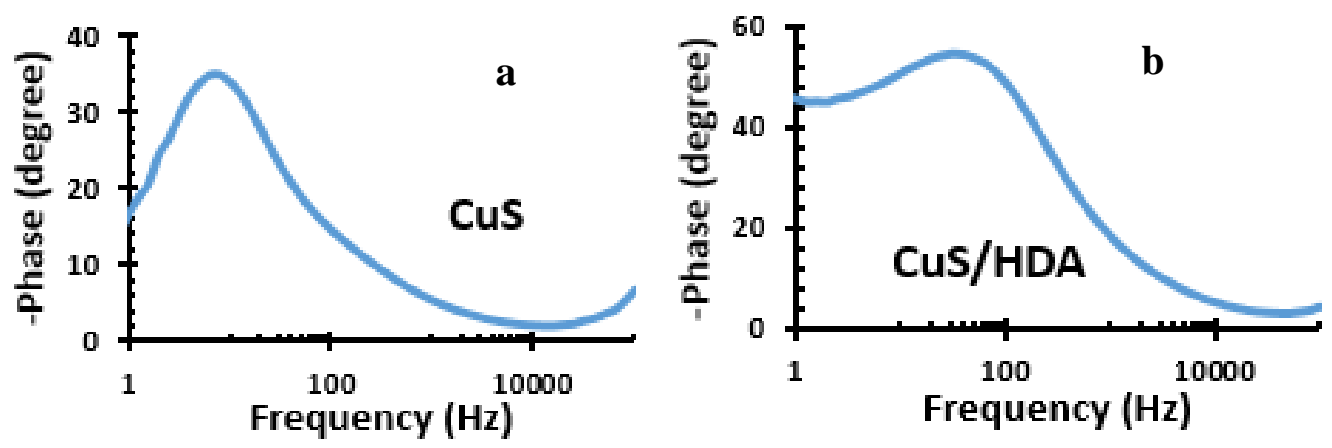

Figure 6. Bode plot spectra of (a) CuS and (b) CuS/HDA nanoparticles.
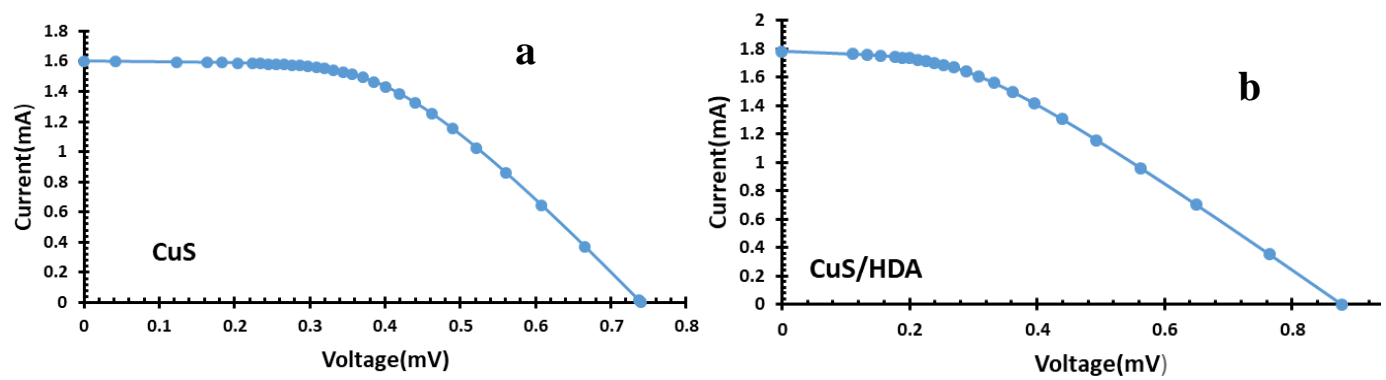

Figure 7. I-V curve characteristics of (a) CuS and (b) CuS/HDA nanoparticles.

\subsection{Bode Plot of Metal Sulfide Nanoparticles}

Figure 6 shows the Bode plots of the QDSSCs. The electron lifetimes were obtained from peak angular frequency (fmax). Moreover, the lower $\tau$ in in CuS/HDA suggested that electrons had a longer lifetime than those of CuS, and that they were effectively transferred, resulting in higher Jsc and energy-conversion efficiency for CuS/HDA. Jsc increase resulted in good electrocatalytic activity and electron-transport behaviour. The $\mathrm{CuS} / \mathrm{HDA}$ on $\mathrm{TiO}_{2}$ remarkably decreased the recombination of photo-injected electrons with the redox electrolyte compared to CuS photosensitiser. CuS displayed very low electron lifetime as a result of an excess amount of $\mathrm{CuS}$ ions, which increased photoanode resistance and recombination for the electrolyte. This accounted for low fill factor (FF), and affected the performance of the CuS photosensitiser [55-60].

\subsection{I-V Results}

Table 1 and Figure 7 show the photocurrent-voltage I-V summary for cells of CuS/HDA and CuS. They compare I-V analysis on the basis of efficiency (\%),open-circuit voltage (Voc), FF, and Jsc. Efficiencies of $0.15 \%$ for CuS/HDA and $0.01 \%$ for CuS were revealed from the measurement. The $\mathrm{CuS} / \mathrm{HDA}$ photosensitiser showed Jsc at $1.78 \mathrm{~mA} \mathrm{~cm}^{-2}$, FF value at 0.1 , and conversion efficiency at $0.15 \%$, which is similar to the report by Kim et al., [61], compared to that of the CuS cell $(0.01 \%)$. The electrolyte interface suggested that recaptured holes could be the reason for low values in the Jsc and FF of CuS compared to those of CuS/HDA [61,62]. It is well known that enhancement in charge transfer at the $\mathrm{CE} /$ electrolyte interface reduces recombination rates, internal resistances, and concentration gradients in the electrolyte, resulting in a higher fill factor and Jsc [63]. The higher I-V characteristics depicted in CuS/HDA was linked to lower Rct, increased electrocatalytic activity, and relatively higher surface roughness, as displayed in AFM, CV, and EIS [64]. 
Table 1. I-V characteristics of (a) CuS/HDA and (b) CuS nanoparticles. FF, fill factor.

\begin{tabular}{cccccccc}
\hline Dye & Photoanode & Electrolyte & CEs & $\begin{array}{c}J_{S C} \\
\left(\mathbf{m A} / \mathbf{c m}^{2}\right)\end{array}$ & $V_{O C}(\mathbf{m V})$ & FF & $\eta(\%)$ \\
\hline CUS/HDA & $\mathrm{TiO}_{2}$ & $\mathrm{HI}-30$ & $\mathrm{Pt}$ & 1.78 & 0.877 & 0.1 & 0.15 \\
CUS & $\mathrm{TiO}_{2}$ & $\mathrm{HI}-30$ & $\mathrm{Pt}$ & 0.64 & 0.068 & 0.3 & 0.01 \\
\hline
\end{tabular}

\section{Materials and Methods}

\subsection{Materials}

All material solvents and complexes were purchased from Merck (Johannasburg, South Afriac) and used without further purification, while the testing kits were purchased from Solaronix (Aubonne, Switzerland). The complete test kits containing FTO as glass substrate of $\mathrm{TiO}_{2}$, platinum FTO, HI-30 electrolyte iodide, masks, gaskets, chenodeoxycholic acid (CDC), and hot seal were purchased from Solaronix. Water, OA, methanol, HDA and (bis(N-1,4-phenyl-N-(4-morpholinedithiocarbamato)copper(II) complexes) Merck (Johannasburg, South Afriac).

\subsection{Synthesis of CuS Nanoparticles with HDA Capping Agent}

Nanoparticles were fabricated according to the literature method [65]. Then, $0.20 \mathrm{~g}$ (bis(N-1,4-phenyl-N-(4-morpholinedithiocarbamato)copper(II) complexes) was dissolved in $4 \mathrm{~mL}$ ofOA and injected into $3 \mathrm{~g}$ of hot HDA at $360{ }^{\circ} \mathrm{C}$. An initial temperature of $20-30{ }^{\circ} \mathrm{C}$ was attained for the mixture. The reaction was stabilised at $360^{\circ} \mathrm{C}$, and the process lasted for $1 \mathrm{~h}$. When the temperature of the mixture dropped to $70{ }^{\circ} \mathrm{C}$, this signified the completion of the process, and about $50 \mathrm{~mL}$ methanol was used to remove excess OA and HDA. Centrifugation was used to separate the flocculent precipitate, and redispersed with toluene. Low air pressure was used to remove the solvent, giving rise to the metal sulfides of $\mathrm{CuS} / \mathrm{HDA}$ nanoparticles.

\subsection{Synthesis of CuS Nanoparticles without HDA Capping Agent}

Synthesis of CuS nanocrystals was obtained through the high-temperature thermal decomposition of (bis(N-1,4-phenyl-N-(4-morpholinedithiocarbamato)copper(II)) complexes according to [66] using a Perkin Elmer 4000 ThermoGravimetric Analyser. Approximately $25 \mathrm{mg}$ of the complex was loaded into an alumina pan, and weight changes were recorded as a function of temperature for a $10^{\circ} \mathrm{C} \mathrm{min}-1$ temperature gradient between 30 and $900{ }^{\circ} \mathrm{C}$. A purge gas of flowing nitrogen at a rate of $20 \mathrm{~mL} \mathrm{~min}^{-1}$ was used. At temperatures between 360 and $900^{\circ} \mathrm{C}$, the complex end product was converted into residue, which was expected for the formation of $\mathrm{CuS}$ nanocrystals from the residue obtained from the TGA (Perkin Elmer 4000 ThermoGravimetric Analyser, San Jose, CA, USA).

\subsection{Solar-Cell Fabrication and Assembly}

QDSSCs were prepared with $2 \times 2 \mathrm{~cm}$ FTO glass plates of platinum. $\mathrm{TiO}_{2}$ electrodes were purchased from Solaronix with a $6 \times 6 \mathrm{~mm}^{\mathrm{p}}$ active area of $\mathrm{TiO}_{2}$ screen coated. Dye loading for sensitisation was done using $10 \mathrm{~mL}$ of warm water with CuS/HDA and CuS. Coadsorbents were added (coadsorbent/dye), and chenodeoxycholic acid (CDC) was used. The mediating solution was the commercial HI-30 electrolyte solution (Solaronix, Aubonne, Switzerland), with the content of iodide species at $0.05 \mathrm{M}$. The $\mathrm{TiO}_{2}$ thin film was soaked into a solution of photosensitisers for $24 \mathrm{~h}$. The two substrates, one coated with $\mathrm{TiO}_{2}$ loaded with photosensitisers and the other with platinum, were held together using polyethylene and soldering iron. A syringe was used to inject the HI-30 electrolyte (iodide). 
Characterisation and solar-cell conversion-efficiency (\%) measurements were done using Equations (1)-(4) below. All substitutions were done following Equations (1)-(4).

$$
\begin{gathered}
\mathrm{Jsc}=(\mathrm{Isc}(\mathrm{mA})) /\left(\mathrm{A}\left(\mathrm{cm}^{2}\right)\right) \\
\mathrm{FF}=(\operatorname{Vmax} \times \mathrm{Jmax}) /(\operatorname{Voc} \times \mathrm{Jsc})
\end{gathered}
$$

where FF is fill factor, and Voc is an open circuit voltage; Jsc is a short circuit current density.

$$
\eta(\%)=(\operatorname{Vmax} \times \operatorname{Jmax}) / \operatorname{Pin}
$$

The above equation was adopted where Pin is a light intensity of $100 \mathrm{~mW} \mathrm{~cm}^{-2}$.

$$
\eta(\%)=(\operatorname{Voc} \times \mathrm{Jsc} \times \mathrm{FF}) / \mathrm{Pin} \times 100 \%
$$

The final equation for overall conversion efficiency was derived from the following equation.

\subsection{Characterisation}

Electrochemical studies were carried out using Metrohm 85695 Autolab with Nova 1.10 software. A platinum electrode was adopted as a counter electrode, and $\mathrm{TiO}_{2}$ as the anode. An HI-30 iodode electrode (Metrohm South Africa (Pty) Ltd) was used as a reference electrode. The CV was performed at scan rates between 0.05 and $0.35 \mathrm{~V} \mathrm{~s}^{-1}$ with an increment of $0.05 \mathrm{~V} \mathrm{~s}^{-1}$. All experiments were performed at room temperature. EIS was carried out in the frequency range of 100 to $100 \mathrm{mHz}$. I-V parameters were collected through a Keithley 2401 source meter and a Thorax light power meter (RS Components (SA) South Africa). A Lumixo AM1.5 light simulator was employed, and the lamp was fixed at $50 \mathrm{~cm}$ high to avoid illumination outside of the working area. To avoid cell degradation, temperature was kept below $60^{\circ} \mathrm{C}$, and light-power density was maintained at $100 \mathrm{~mW} \mathrm{~cm}{ }^{-2}$ (AM1.0). An X-ray diffractometer (Cambridge, CB, United Kingdom) was employed to evaluate the structural pattern of the samples, and the diffraction structure was obtained between $10^{\circ}$ and $90^{\circ}$ at intervals of $0.05^{\circ}$. The surface roughness of the $\mathrm{CuS}$ and CuS/HDA FTO substrates was identified through the use of AFM (JPK NanoWizard II AFM, JPK Instruments, Berlin, Germany) at a scan rate of $0.8 \mathrm{~Hz}$ in contact mode. A field emission scanning electron microscope (FE-SEM) Zeiss Auriga SEM (Munich, Germany) outfitted with Smart SEM programming was utilised to study the morphological properties at a quickening voltage of $30 \mathrm{KV}$.

\section{Conclusions}

In summary, CuS and CuS/HDA QD photosensitisers were synthesised using single-source-precursor and direct-deposition techniques. The characterisation results confirmed that both samples had hexagonal nanostructures and interesting conversion output by CuS/HDA. Surface roughness improved the electrocatalytic performance of $\mathrm{CuS} / \mathrm{HDA}$ on $\mathrm{TiO}_{2}$ by reducing surface resistivity, which implied improved conversion efficiency. The CuS/HDA photosensitiser suggested appropriate lifetime and electron transfer compared to CuS, which demonstrated a lower electron lifetime. Higher electrocatalytic activity and interfacial resistance further cemented the CuS/HDA as a superior photosensitiser.

Author Contributions: Conceptualisation, J.Z.M., M.A.A., and E.L.M.; methodology, J.Z.M., M.A.A., and E.L.M.; validation, J.Z.M., M.A.A., K.M., and E.L.M.; formal analysis, J.Z.M., M.A.A., K.M., and E.L.M.; investigation, M.A.A. and K.M.; resources, J.Z.M. and E.L.M.; data curation, J.Z.M., M.A.A., and E.L.M.; writing-original-draft preparation, M.A.A.; writing-review and editing, M.A.A.; visualisation, M.A.A.; supervision, J.Z.M. and E.L.M.; funding acquisition, J.Z.M. and E.L.M. All authors have read and agreed to the published version of the manuscript.

Funding: The authors wish to acknowledge the National Department of Science and Technology (GUN: 86187) and the National Research Foundation (GUN: 93215) for financial support. The authors are also grateful for the 
financial support by the Govan Mbeki Research and Development Centre (GMRDC), University of Fort Hare, South Africa, and the NRF Thuthuka Grant (GUN: 118139), Eskom TESP (P948)

Acknowledgments: The authors appreciate the support from Kbizz IT support for the data visualisation.

Conflicts of Interest: The authors declare no conflict of interest.

\section{References}

1. Kundu, J.; Khilari, S.; Bhunia, K.; Pradhan, D. Ni-Doped CuS as an efficient electrocatalyst for the oxygen evolution reaction. Catal. Sci. Technol. 2019, 9, 406-417. [CrossRef]

2. Graetzel, M.; Janssen, R.A.; Mitzi, D.B.; Sargent, E.H. Materials interface engineering for solution-processed photovoltaics. Nature 2012, 488, 304-312. [CrossRef] [PubMed]

3. Dreos, A.; Börjesson, K.; Wang, Z.; Roffey, A.; Norwood, Z.; Kushnir, D.; Moth-Poulsen, K. Exploring the potential of a hybrid device combining solar water heating and molecular solar thermal energy storage. Energy Environ. Sci. 2017, 10, 728-734. [CrossRef]

4. Sleiti, A.K. Tidal power technology review with potential applications in Gulf Stream. Renew. Sustain. Energy Rev. 2017, 69, 435-441. [CrossRef]

5. Singh, V.K.; Singal, S.K. Operation of hydro power plants-a review. Renew. Sustain. Energy Rev. 2017, 69, 610-619. [CrossRef]

6. Singh, G.K. Solar power generation by PV (photovoltaic) technology: A review. Energy 2013, 53, 1-13. [CrossRef]

7. Ali, N.; Hussain, A.; Ahmed, R.; Wang, M.K.; Zhao, C.; Haq, B.U.; Fu, Y.Q. Advances in nanostructured thin film materials for solar cell applications. Renew. Sustain. Energy Rev. 2016, 59, 726-737. [CrossRef]

8. Badawy, W.A. A review on solar cells from Si-single crystals to porous materials and quantum dots. J. Adv. Res. 2015, 6, 123-132. [CrossRef]

9. Lai, L.H.; Protesescu, L.; Kovalenko, M.V.; Loi, M.A. Sensitized solar cells with colloidal PbS-CdS core-shell quantum dots. Phys. Chem. Chem. Phys. 2014, 16, 736-742. [CrossRef]

10. Zheng, Z.; Ji, H.; Yu, P.; Wang, Z. Recent progress towards quantum dot solar cells with enhanced optical absorption. Nanoscale Res. Lett. 2016, 11, 266. [CrossRef]

11. Li, W.; Pan, Z.; Zhong, X. CuInSe 2 and CuInSe 2 ZnS based high efficiency "green" quantum dot sensitized solar cells. J. Mater. Chem. A 2015, 3, 1649-1655. [CrossRef]

12. Duan, J.; Zhang, H.; Tang, Q.; He, B.; Yu, L. Recent advances in critical materials for quantum dot-sensitized solar cells: A review. J. Mater. Chem. A 2015, 3, 17497-17510. [CrossRef]

13. Jara, D.H.; Yoon, S.J.; Stamplecoskie, K.G.; Kamat, P.V. Size-dependent photovoltaic performance of CuInS 2 quantum dot-sensitized solar cells. Chem. Mater. 2014, 26, 7221-7228. [CrossRef]

14. Luo, J.; Sun, J.; Guo, P.C.; Yang, Z.S.; Wang, Y.X.; Zhang, Q.F. Enhancement in efficiency of CdS/CdSe quantum dots-sensitized solar cells based on $\mathrm{ZnO}$ nanostructures by introduction of MnS layer. Mater. Lett. 2018, 215, 176-178. [CrossRef]

15. Oluwafemi, O.S. Quantum dots for solar cell applications. In Nanomaterials for Solar Cell Applications; Elsevier: Amsterdam, The Netherlands, 2019; pp. 377-415. [CrossRef]

16. Isac, L.; Cazan, C.; Alexandru, E.; Andronic, L. Copper Sulfide Based Heterojunctions as Photocatalysts for Dyes Photodegradation. Front. Chem. 2019, 7, 694. [CrossRef]

17. Zhang, K.; Jin, L.; Yang, Y.; Guo, K.; Hu, F. Novel method of constructing CdS/ZnS heterojunction for high performance and stable photocatalytic activity. J. Photochem. Photobiol. A Chem. 2019, 380, 111859. [CrossRef]

18. Coughlan, C.; Ibanez, M.; Dobrozhan, O.; Singh, A.; Cabot, A.; Ryan, K.M. Compound copper chalcogenide nanocrystals. Chem. Rev. 2017, 117, 5865-6109. [CrossRef]

19. Liu, Y.; Liu, M.; Swihart, M.T. Plasmonic copper sulfide-based materials: A brief Introduction to their synthesis, doping, alloying, and applications. J. Phys. Chem. C 2017, 121, 13435-13447. [CrossRef]

20. Lian, Z.; Sakamoto, M.; Matsunaga, H.; Vequizo, J.J.M.; Yamakata, A.; Haruta, M.; Kurata, H.; Ota, W.; Sato, T.; Teranishi, T. Near infrared light induced plasmonic hot hole transfer at a nano-heterointerface. Nat. Commun. 2018, 9, 1-7. [CrossRef]

21. Van der Stam, W.; Gudjonsdottir, S.; Evers, W.H.; Houtepen, A.J. Switching between plasmonic and fluorescent copper sulfide nanocrystals. J. Am. Chem. Soc. 2017, 139, 13208-13217. [CrossRef] 
22. Liu, Y.; Liu, M.; Swihart, M.T. Reversible crystal phase interconversion between covellite CuS and high chalcocite Cu2S nanocrystals. Chem. Mater. 2017, 29, 4783-4791. [CrossRef]

23. Toe, C.Y.; Zheng, Z.; Wu, H.; Scott, J.; Amal, R.; Ng, Y.H. Transformation of cuprous oxide into hollow copper sulfide cubes for photocatalytic hydrogen generation. J. Phys. Chem. C 2018, 122, 14072-14081. [CrossRef]

24. Deng, X.; Wang, C.; Yang, H.; Shao, M.; Zhang, S.; Wang, X.; Ding, M.; Huang, J.; Xu, X. One-pot hydrothermal synthesis of CdS decorated CuS microflower-like structures for enhanced photocatalytic properties. Sci. Rep. 2017, 7, 1-12. [CrossRef] [PubMed]

25. Xu, L.; Zhang, X.; Shen, Y.; Ding, Y.; Wang, L.; Sheng, Y. Durable superhydrophobic cotton textiles with ultraviolet-blocking property and photocatalysis based on flower-like copper sulfide. Ind. Eng. Chem. Res. 2018, 57, 6714-6725. [CrossRef]

26. Nethravathi, C.; Rajamathi, J.T.; Rajamathi, M. Microwave-assisted synthesis of porous aggregates of CuS nanoparticles for sunlight photocatalysis. ACS Omega 2019, 4, 4825-4831. [CrossRef]

27. Jiang, Y.; Zhang, M.; Xin, Y.; Chai, C.; Chen, Q. Construction of immobilized $\mathrm{CuS} / \mathrm{TiO}_{2}$ nanobelts heterojunction photocatalyst for photocatalytic degradation of enrofloxacin: Synthesis, characterization, influencing factors and mechanism insight. J. Chem. Technol. Biotechnol. 2019, 94, 2219-2228. [CrossRef]

28. Rühle, S.; Shalom, M.; Zaban, A. Quantum-dot-sensitized solar cells. ChemPhysChem. 2010, 11, $2290-2304$. [CrossRef]

29. Meyer, E.L.; Mbese, J.Z.; Agoro, M.A. The Frontiers of Nanomaterials (SnS, PbS and CuS) for Dye-Sensitized Solar Cell Applications: An Exciting New Infrared Material. Molecules 2019, 24, 4223. [CrossRef]

30. Li, Y.; Hu, J.; Liu, G.; Zhang, G.; Zou, H.; Shi, J. Amylose-directed synthesis of CuS composite nanowires and microspheres. Carbohydr. Polym. 2013, 92, 555-563. [CrossRef]

31. Chaki, S.H.; Deshpande, M.P.; Tailor, J.P. Characterization of CuS nanocrystalline thin films synthesized by chemical bath deposition and dip coating techniques. Thin Solid Film. 2014, 550, 291-297. [CrossRef]

32. Kanzari, M.; Abaab, M.; Rezig, B.; Brunel, M. Effect of substrate thermal gradient on as-grown CuInS 2 properties. Mater. Res. Bull. 1997, 32, 1009-1015. [CrossRef]

33. Mousavi-Kamazani, M.; Zarghami, Z.; Salavati-Niasari, M. Facile and novel chemical synthesis, characterization, and formation mechanism of copper sulfide $\left(\mathrm{Cu}_{2} \mathrm{~S}, \mathrm{Cu}_{2} \mathrm{~S} / \mathrm{CuS}, \mathrm{CuS}\right)$ nanostructures for increasing the efficiency of solar cells. J. Phys. Chem. 2016, 120, 2096-2108. [CrossRef]

34. Naveenkumar, P.; Kalaignan, G.P.; Arulmani, S.; Anandan, S. Solvothermal synthesis of CuS/Cu $(\mathrm{OH})_{2}$ nanocomposite electrode materials for supercapacitor applications. J. Mater. Sci. Mater. Electron. 2018, 29, 16853-16863. [CrossRef]

35. Jeon, S.S.; Kim, C.; Lee, T.H.; Lee, Y.W.; Do, K.; Ko, J.; Im, S.S. Camphorsulfonic acid-doped polyaniline transparent counter electrode for dye-sensitized solar cells. J. Phys. Chem. C 2012, 116, 22743-22748. [CrossRef]

36. Rao, S.S.; Durga, I.K.; Kang, T.S.; Kim, S.K.; Punnoose, D.; Gopi, C.V.; Reddy, A.E.; Krishna, T.N.V.; Kim, H.J. Enhancing the photovoltaic performance and stability of QDSSCs using surface reinforced Pt nanostructures with controllable morphology and superior electrocatalysis via cost-effective chemical bath deposition. Dalton Trans. 2016, 45, 3450-3463. [CrossRef] [PubMed]

37. Al-Douri, Y.; Khasawneh, Q.; Kiwan, S.; Hashim, U.; Hamid, S.A.; Reshak, A.H.; Bouhemadou, A.; Ameri, M.; Khenata, R. Structural and optical insights to enhance solar cell performance of CdS nanostructures. Energy Convers. Manag. 2014, 82, 238-243. [CrossRef]

38. Hsu, Y.K.; Chen, Y.C.; Lin, Y.G. Synthesis of copper sulfide nanowire arrays for high-performance supercapacitors. Electrochim. Acta 2014, 139, 401-407. [CrossRef]

39. Elgrishi, N.; Rountree, K.J.; McCarthy, B.D.; Rountree, E.S.; Eisenhart, T.T.; Dempsey, J.L. A practical beginner's guide to cyclic voltammetry. J. Chem. Educ 2018, 95, 197-206. [CrossRef]

40. Shim, J.J. In situ growth of hierarchical mesoporous $\mathrm{NiCo}_{2} \mathrm{~S}_{4} @ \mathrm{MnO}_{2}$ arrays on nickel foam for high-performance supercapacitors. Electrochim. Acta 2015, 166, 302-309. [CrossRef]

41. Sarac, U.; Öksüzoğlu, R.M.; Baykul, M.C. Deposition potential dependence of composition, microstructure, and surface morphology of electrodeposited Ni-Cu alloy films. J. Mater. Sci. Mater. Electron. 2012, 23, 2110-2116. [CrossRef]

42. Metosen, A.; Bin, A.N.S.; Pang, S.C.; Chin, S.F. Nanostructured multilayer composite films of manganese dioxide/nickel/copper sulfide deposited on polyethylene terephthalate supporting substrate. J. Nanomater. 2015. [CrossRef] 
43. Himasree, P.; Durga, I.K.; Krishna, T.N.V.; Rao, S.S.; Gopi, C.V.M.; Revathi, S.; Prabakar, K.; Kim, H.J. One-step hydrothermal synthesis of CuS@MnS on Ni foam for high performance supercapacitor electrode material. Electrochim. Acta 2019, 305, 467-473. [CrossRef]

44. Zhang, X.; Shi, W.; Zhu, J.; Zhao, W.; Ma, J.; Mhaisalkar, S.; Maria, T.L.; Yang, Y.; Zhang, H.; Hng, H.H.; et al. Synthesis of porous $\mathrm{NiO}$ nanocrystals with controllable surface area and their application as supercapacitor electrodes. Nano Res. 2010, 3, 643-652. [CrossRef]

45. Gund, G.S.; Dubal, D.P.; Jambure, S.B.; Shinde, S.S.; Lokhande, C.D. Temperature influence on morphological progress of $\mathrm{Ni}(\mathrm{OH})_{2}$ thin films and its subsequent effect on electrochemical supercapacitive properties. J. Mater. Chem. A 2013, 1, 4793-4803. [CrossRef]

46. Yue, G.; Lin, J.Y.; Tai, S.Y.; Xiao, Y.; Wu, J. A catalytic composite film of $\mathrm{MoS}_{2} /$ graphene flake as a counter electrode for Pt-free dye-sensitized solar cells. Electrochim. Acta 2012, 85, 162-168. [CrossRef]

47. Liu, I.P.; Teng, H.; Lee, Y.L. Highly electrocatalytic carbon black/copper sulfide composite counter electrodes fabricated by a facile method for quantum-dot-sensitized solar cells. J. Mater. Chem. A 2017, 5, 23146-23157. [CrossRef]

48. Khalili, S.S.; Dehghani, H. Ca-doped CuS/graphene sheet nanocomposite as a highly catalytic counter electrode for improving quantum dot-sensitized solar cell performance. RSC Adv. 2016, 6, 10880-10886. [CrossRef]

49. Liu, C.J.; Tai, S.Y.; Chou, S.W.; Yu, Y.C.; Chang, K.D.; Wang, S.; Chien, F.S.S.; Lin, J.Y.; Lin, T.W. Facile synthesis of $\mathrm{MoS}_{2}$ /graphene nanocomposite with high catalytic activity toward triiodide reduction in dye-sensitized solar cells. J. Mater. Chem. 2012, 22, 21057-21064. [CrossRef]

50. Patil, S.A.; Kalode, P.Y.; Mane, R.S.; Shinde, D.V.; Doyoung, A.; Keumnam, C.; Sung, M.M.; Ambade, S.B.; Han, S.H. Highly efficient and stable DSSCs of wet-chemically synthesized $\mathrm{MoS}_{2}$ counter electrode. Dalton Trans. 2014, 43, 5256-5259. [CrossRef]

51. Mohammadnezhad, M.; Selopal, G.S.; Alsayyari, N.; Akilimali, R.; Navarro-Pardo, F.; Wang, Z.M.; Stansfield, B.; Zhao, H.; Rosei, F. CuS/Graphene Nanocomposite as a Transparent Conducting Oxide and Pt-Free Counter Electrode for Dye-Sensitized Solar Cells. J. Electrochem. Soc. 2019, 166, H3065-H3073. [CrossRef]

52. Guan, S.T.; Yang, H.; Sun, X.F.; Xian, T. Preparation and promising application of novel $\mathrm{LaFeO}_{3} / \mathrm{BiOBr}$ heterojunction photocatalysts for photocatalytic and photo-Fenton removal of dyes. Opt. Mater. 2020, 100, 109644. [CrossRef]

53. Wang, S.; Gao, H.; Chen, C.; Wei, Y.; Zhao, X. Irradiation assisted polyacrylamide gel route for the synthesize of the $\mathrm{Mg}_{1-\mathrm{x}} \mathrm{CoxAl}_{2} \mathrm{O}_{4}$ nano-photocatalysts and its optical and photocatalytic performances. J. Sol-Gel Sci. Technol. 2019, 92, 186-199. [CrossRef]

54. Wang, Y.; Jiang, F.; Chen, J.; Sun, X.; Xian, T.; Yang, H. In Situ Construction of CNT/CuS Hybrids and Their Application in Photodegradation for Removing Organic Dyes. Nanomaterials 2020, 10, 178. [CrossRef]

55. Chen, H.W.; Liang, C.P.; Huang, H.S.; Chen, J.G.; Vittal, R.; Lin, C.Y.; Wu, K.C.W.; Ho, K.C. Electrophoretic deposition of mesoporous $\mathrm{TiO}_{2}$ nanoparticles consisting of primary anatase nanocrystallites on a plastic substrate for flexible dye-sensitized solar cells. Chem. Commun. 2011, 47, 8346-8348. [CrossRef] [PubMed]

56. Rao, S.S.; Gopi, C.V.; Kim, S.K.; Son, M.K.; Jeong, M.S.; Savariraj, A.D.; Prabakar, K.; Kim, H.J. Cobalt sulfide thin film as an efficient counter electrode for dye-sensitized solar cells. Electrochim. Acta 2014, 133, 174-179. [CrossRef]

57. Thulasi-Varma, C.V.; Rao, S.S.; Kumar, C.S.S.P.; Gopi, C.V.; Durga, I.K.; Kim, S.K.; Punnoose, D.; Kim, H.J. Enhanced photovoltaic performance and time varied controllable growth of a CuS nanoplatelet structured thin film and its application as an efficient counter electrode for quantum dot-sensitized solar cells via a cost-effective chemical bath deposition. Dalton Trans. 2015, 44, 19330-19343. [CrossRef] [PubMed]

58. Rao, S.S.; Punnoose, D.; Tulasivarma, C.V.; Kumar, C.P.; Gopi, C.V.; Kim, S.K.; Kim, H.J. A strategy to enhance the efficiency of dye-sensitized solar cells by the highly efficient TiO2/ZnS photoanode. Dalton Trans. 2015, 44, 2447-2455. [CrossRef]

59. Park, N.G.; Kang, M.G.; Kim, K.M.; Ryu, K.S.; Chang, S.H.; Kim, D.K.; Van de Lagemaat, J.; Benkstein, K.D.; Frank, A.J. Morphological and photoelectrochemical characterization of core- shell nanoparticle films for dye-sensitized solar cells: $\mathrm{Zn}^{-} \mathrm{O}$ type shell on $\mathrm{SnO}_{2}$ and $\mathrm{TiO}_{2}$ cores. Langmuir 2004, 20, 4246-4253. [CrossRef]

60. Lin, C.Y.; Teng, C.Y.; Li, T.L.; Lee, Y.L.; Teng, H. Photoactive p-type PbS as a counter electrode for quantum dot-sensitized solar cells. J. Mater. Chem. A 2013, 1, 1155-1162. [CrossRef] 
61. Kim, H.J.; Kim, J.H.; Kumar, C.S.P.; Punnoose, D.; Kim, S.K.; Gopi, C.V.; Rao, S.S. Facile chemical bath deposition of CuS nano peas like structure as a high efficient counter electrode for quantum-dot sensitized solar cells. J. Electroanal. Chem. 2015, 739, 20-27. [CrossRef]

62. Zhou, R.; Niu, H.; Ji, F.; Wan, L.; Mao, X.; Guo, H.; Xu, J.; Cao, G. Band-structure tailoring and surface passivation for highly efficient near-infrared responsive PbS quantum dot photovoltaics. J. Power Sources 2016, 333, 107-117. [CrossRef]

63. Muhyuddin, M.; Ahsan, M.T.; Ali, I.; Khan, T.F.; Akram, M.A.; Basit, M.A. A new insight into solar paint concept: Regeneration of CuS nanoparticles for paintable counter electrodes in QDSSCs. Appl. Phys. A 2019, 125, 716. [CrossRef]

64. Kalanur, S.S.; Chae, S.Y.; Joo, O.S. Transparent Cu1. 8S and CuS thin films on FTO as efficient counter electrode for quantum dot solar cells. Electrochim. Acta 2013, 103, 91-95. [CrossRef]

65. Mbese, J.Z.; Ajibade, P.A.; Matebese, F.; Agoro, M.A. Optical and Structural Properties of TOPO/HDA Capped CuS-Nanocrystals via Thermal Decomposition of Bis( $\mathrm{N}$-Diisopropyldithiocarbamate) $\mathrm{Cu}(\mathrm{II})$ Complex. J. Nano Res. 2019, 59, 161-165. [CrossRef]

66. Meyer, E.L.; Mbese, J.Z.; Agoro, M.A.; Taziwa, R. Optical and structural-chemistry of SnS nanocrystals prepared by thermal decomposition of bis( $N$-di-isopropyl- $N$-octyldithiocarbamato)tin(II) complex for promising materials in solar cell applications. Opt. Quant. Electron. 2020, 52, 90. [CrossRef]

(C) 2020 by the authors. Licensee MDPI, Basel, Switzerland. This article is an open access article distributed under the terms and conditions of the Creative Commons Attribution (CC BY) license (http://creativecommons.org/licenses/by/4.0/). 